\title{
PENGETAHUAN IBU HAMIL TENTANG KONTRASEPSI \\ DI BAGIAN OBSTETRI DAN GINEKOLOGI BLU RSUP PROF. DR. R. D. KANDOU MANADO
}

\author{
${ }^{1}$ Sitti Sakamole \\ ${ }^{2}$ Freddy Wagey \\ ${ }^{3}$ Maria Loho
}

\begin{abstract}
Bagian Obstetri dan Ginekologi Fakultas Kedokteran Universitas Sam Ratulangi Manado Email: liasakamole@ymail.com
\end{abstract}

\begin{abstract}
The high population growth rate, maternal mortality problem, and the low number of new family planning participants led to important need of contraceptive knowledge. Pregnant women as those who have an interest to use postpartum contraception are expected to have good contraceptive knowledge that can increase the effectiveness of contraceptive use and avoid high-risk pregnancies. This research used an analytic survey method with a cross sectional study through questionnaire. Only half respondents had a good contraceptive knowledge. There is no relationship between the age of pregnant women and the contraceptive knowledge. There is a relationship between the education of pregnant women and the contraceptive knowledge. There is a relationship between the job of pregnant women and the contraceptive knowledge. Most pregnant women whose have good contraceptive knowledge is pregnant women with age more than 35 years, high school educated and working.
\end{abstract}

Keywords: pregnant women, contraception, contraceptive knowledge

\begin{abstract}
Abstrak: Angka pertumbuhan penduduk yang tinggi, kematian maternal dan rendahnya jumlah peserta KB baru menyebabkan pengetahuan mengenai kontrasepsi penting untuk diketahui. Ibu hamil sebagai pihak yang memiliki kepentingan untuk menggunakan alat kontrasepsi pascapersalinan diharapkan memiliki pengetahuan yang baik mengenai kontrasepsi sehingga efektivitas penggunaan kontrasepsi bisa meningkat dan menghindari kehamilan resiko tinggi. Penelitian ini menggunakan metode survei analitik dengan studi cross sectional melalui kuesioner. Penelitian ini menggunakan metode deskriptif retrospektif dengan menggunakan data catatan medik pasien. Hasil penelitian yaitu hanya setengah responden yang memiliki pengetahuan baik tentang kontrasepsi. Tidak ada hubungan antara usia ibu hamil dan pengetahuan tentang kontrasepsi. Ada hubungan antara pendidikan dan pengetahuan tentang kontrasepsi. Ada hubungan antara pekerjaan dan pengetahuan tentang kontrasepsi. Ibu hamil yang paling banyak memiliki pengetahuan baik tentang kontrasepsi adalah ibu hamil dengan usia lebih dari 35 tahun, berpendidikan SMA dan bekerja.
\end{abstract}

Kata kunci: ibu hamil, kontrasepsi, pengetahuan kontrasepsi

Berdasarkan sensus penduduk tahun 2010 diketahui bahwa pertumbuhan penduduk melebihi proyeksi nasional yaitu sebesar 237,6 juta jiwa dengan laju pertumbuhan penduduk (LPP) 1,49\% per tahun. ${ }^{1}$ Jumlah penduduk yang besar tanpa disertai dengan kualitas yang memadai, justru menjadi beban pembangunan dan menyulitkan pemerintah dalam meningkatkan pertumbuhan ekonomi dan pembangunan nasional. $^{2}$ Keluarga Berencana adalah upaya mengatur kelahiran anak, jarak dan 
usia ideal melahirkan, mengatur kehamilan, melalui promosi, perlindungan, dan bantuan sesuai dengan hak reproduksi untuk mewujudkan keluarga yang berkualitas. $^{3}$

Kematian maternal juga merupakan masalah besar. Di Indonesia angka kematian maternal sebesar yaitu 390/100.000 persalinan. ${ }^{4}$ Proses reproduksi yang berlangsung terlalu giat, terlalu dini, terlalu banyak dan terlalu rapat, yang umumnya berhubungan dengan kemiskinan, ketidaktahuan dan kebodohan di duga erat menjadi penyebab angka kematian ibu yang tinggi ini. $^{5} \mathrm{~KB}$ merupakan salah satu dari 4 pilar safe motherhood sebagai upaya dalam menurunkan angka kematian maternal ini. ${ }^{6}$

Berdasarkan laporan hasil pelayanan kontrasepsi bulan juli 2013 dari BKKBN peserta KB baru nasional mencapai 4.856.618 peserta, dan pencapaian peserta KB Baru di Provinsi Sulawesi Utara baru mencapai 18,02\%. ${ }^{7} \quad$ Berdasarkan dari uraian di atas mengenai tingginya angka pertumbuhan penduduk yang tinggi, kematian maternal serta jumlah peserta KB baru yang rendah menyebabkan pengetahuan mengenai kontrasepsi dipandang penting untuk diketahui.

\section{METODE}

Penelitian ini menggunakan metode survei analitik dengan studi cross sectional melalui kuesioner. Subjek penelitian yaitu semua ibu hamil yang melakukan pemeriksaan antenatal di bagian Obstetri dan Ginekologi BLU RSUP Prof. DR. R. D. Kandou Manado pada bulan Desember 2013. Penelitian dilakukan selama bulan Desember 2013 di ruang tunggu Poliklinik Obstetri dan Ginekologi BLU RSUP Prof. Dr. R. D. Kandou Manado. Variabel penelitian adalah pengetahuan ibu hamil tentang kontrasepsi, usia, pendidikan dan pekerjaan.

\section{HASIL}

Dari seluruh ibu yang melakukan pemeriksaan antenatal di bagian Obstetri dan Ginekologi pada bulan Desember 2013 diambil secara acak 50 orang responden sebagai subjek penelitian.

Pada variabel usia, pendidikan dan pekerjaan sesuai Tabel 1 didapatkan bahwa ibu hamil yang melakukan pemeriksaan antenatal paling banyak berada pada usia lebih dari 35 tahun, berpendidikan tamat SMA dan tidak bekerja.

Tabel 1. Karakteristik Responden

\begin{tabular}{ccc}
\hline Usia & Jumlah & \% \\
\hline$<20$ tahun & 2 & 4 \\
20-25 tahun & 13 & 26 \\
26-30 tahun & 8 & 16 \\
31-35 tahun & 10 & 20 \\
$>35$ tahun & 17 & 34 \\
Pendidikan & & \\
Tidak Tamat SD & 0 & 0 \\
Tamat SD & 3 & 6 \\
Tamat SMP & 12 & 24 \\
Tamat SMA & 23 & 46 \\
Mahasiswa & 0 & 0 \\
Akademik/D3 & 3 & 6 \\
Perguruan Tinggi & 9 & 18 \\
(S1/S2/S3) & & \\
Pekerjaan & & 36 \\
Bekerja & 18 & $\mathbf{1 0 0}$ \\
\hline Tidak Bekerja & 32 & \\
Total & $\mathbf{5 0}$ &
\end{tabular}

Pada penelitian ini dilihat juga pilihan kontrasepsi yang digunakan ibu sebelum hamil. Kontrasepsi yang paling banyak 
digunakan yaitu Suntik KB sebanyak 20 orang dari total responden (Tabel 2).

Tabel 2. Pilihan Kontrasepsi

\begin{tabular}{ccc}
\hline Pilihan Kontrasepsi & Jumlah & $\mathbf{\%}$ \\
\hline Implant & 4 & 8 \\
Pil KB & 12 & 24 \\
Suntik KB & 20 & 40 \\
Kondom & 2 & 4 \\
IUD & 1 & 2 \\
Tidak memakai KB & 11 & 22 \\
Total & $\mathbf{5 0}$ & $\mathbf{1 0 0}$ \\
\hline
\end{tabular}

Dari total 50 orang responden didapatkan hasil bahwa hanya setengah yang memiliki pengetahuan baik tentang kontrasepsi (Tabel 3).

Tabel 3. Pengetahuan Kontrasepsi

\begin{tabular}{ccc}
\hline $\begin{array}{c}\text { Pengetahuan } \\
\text { Kontrasepsi }\end{array}$ & Jumlah & $\mathbf{\%}$ \\
\hline Baik & 25 & 50 \\
Cukup & 16 & 32 \\
Kurang & 9 & 18 \\
Total & $\mathbf{5 0}$ & $\mathbf{1 0 0}$ \\
\hline
\end{tabular}

Hasil uji analisis Chi-Square variabel usia dan pengetahuan ibu hamil tentang kontrasepsi diperoleh nilai $p=0,527$ ( $p>$ $0,05)$. Hal ini menunjukkan tidak ada hubungan antara usia dan pengetahuan ibu hamil tentang kontrasepsi. Uji analisis chisquare untuk variabel pendidikan dan pengetahuan ibu hamil tentang kontrasepsi diperoleh nilai $p=0,029(p<0,05)$. Hal ini menunjukkan ada hubungan antara pendidikan dan pengetahuan ibu hamil tentang kontrasepsi. Uji analisis ChiSquare untuk variabel pekerjaan dan pengetahuan ibu hamil tentang kontrasepsi diperoleh nilai $p=0,012(p<0,05)$. Hal ini menunjukkan ada hubungan antara perkerjaan dan pengetahuan ibu hamil tentang kontrasepsi.

\section{BAHASAN}

Umur ibu antara 20-35 tahun merupakan usia kehamilan dan kelahiran yang terbaik. ${ }^{8}$ Pada Tabel 1, usia responden terbanyak yaitu > 35 tahun sebanyak 17 orang (34\%), namun bila ditotalkan seluruh jumlah ibu hamil yang berada di antara usia 20-35 tahun maka terdapat sebanyak 31 orang (62\%) yang memenuhi usia produktif terbaik untuk mengandung dan melahirkan.

Pendidikan responden terbanyak adalah tamat SMA. Hal ini sesuai dengan teori menurut Notoadmodjo (2007) bahwa pendidikan mempengaruhi pengetahuan seseorang yaitu semakin tinggi pendidikan maka ia akan mudah menerima hal-hal baru dan mudah menyesuaikan dengan hal yang baru tersebut. ${ }^{9}$ Pendidikan responden yang cukup mempermudah responden untuk menerima informasi.

Sebagian besar responden memilih tidak bekerja dan merupakan ibu rumah tangga. Menurut Dewi dan Wawan (2011), pekerjaan merupakan salah satu faktor internal yang mempengaruhi pengetahuan seseorang. ${ }^{10}$ Namun hal ini harus dilihat juga dari sisi pekerjaan suami, walapun ibu tidak bekerja tapi jika suaminya bekerja maka pendapatan keluarga juga akan meningkat dan berpengaruh pada pendidikan dan pengetahuan dari ibu tersebut.

Metode kontrasepsi yang paling banyak digunakan responden sebelum hamil yaitu suntik KB (Tabel 2). Hal ini sesuai dengan hasil pelayanan peserta KB baru secara nasional pada bulan Juli 2013 dimana peserta suntik $\mathrm{KB}$ adalah yang terbanyak. $^{7}$ Hal yang menarik pada tabel ini yaitu responden yang memilih tidak memakai KB cukup banyak (22\%). Berdasarkan hasil wawancara dengan para 
responden tersebut mereka memilih tidak menggunakan kontrasepsi dengan berbagai alasan antara lain takut dengan efek samping yang bisa ditimbulkan, kurang subur, menganggap dirinya sudah tidak akan hamil lagi karena usia sudah lebih dari 40 tahun kemudian tiba-tiba hamil karena tidak memakai kontrasepsi, dan kebanyakan dari responden memang berencana ingin hamil anak pertama setelah menikah sehingga tidak menggunakan kontrasepsi.

Pengetahuan merupakan hasil dari tahu, dan ini terjadi setelah orang melakukan penginderaan terhadap suatu objek tertentu. ${ }^{11}$ Pada Tabel 3 dapat dilihat bahwa hanya setengah responden yang memiliki pengetahuan baik tentang kontrasepsi. Hal ini berarti penginderaan setengah responden terhadap objek dalam hal ini kontrasepsi sudah baik.

Berdasarkan hasil uji chi-square ditemukan bahwa tidak ada hubungan antara usia dengan pengetahuan ibu hamil tentang kontrasepsi ( $p=0,527)$. Hal ini tidak sesuai dengan Wawan dan Dewi (2011) bahwa usia mempengaruhi daya tangkap dan pola pikir seseorang. Semakin bertambah usia akan semakin berkembang pula daya tangkap dan pola pikirnya, sehingga pengetahuan yang diperolehnya akan semakin membaik. ${ }^{12}$ Perbedaan hasil yang didapatkan mungkin disebabkan oleh jumlah sampel yang terbatas dan banyak faktor lain yang juga ikut mempengaruhi tinggi rendahnya pengetahuan seseorang.

Berdasarkan hasil uji chi-square ditemukan bahwa ada hubungan antara pendidikan dengan pengetahuan ibu hamil tentang kontrasepsi. Hal ini sesuai dengan Nursalam dan Pariani (2004) bahwa semakin tinggi tingkat pendidikan seseorang, maka semakin mudah menerima informasi sehingga semakin banyak pula pengetahuan yang dimilikinya. ${ }^{13}$ Begitu pula dengan Irmayati (2007) bahwa ada beberapa faktor yang mempengaruhi pengetahuan antara lain pendidikan, keterpaparan informasi, dan pengalaman. Semakin tinggi tingkat pendidikan seseorang semakin banyak ilmu dan pengetahuan yang didapatkan. ${ }^{2}$

Pekerjaan adaah sesuatu yang harus dilakukan terutama untuk menunjang kehidupan dan kehidupan keluarga. ${ }^{13}$ Hasil uji chi-square ditemukan bahwa ada hubungan antara pekerjaan dengan pengetahuan ibu hamil tentang kontrasepsi. Hal ini sesuai dengan Wawan dan Dewi (2011) bahwa pekerjaan berhubungan dengan sosial ekonomi seseorang dan sosial ekonomi seseorang berpengaruh kepada pengetahuan. $^{12}$

Pada penelitian ini ditemukan bahwa yang paling banyak tahu tentang kontrasepsi dari total 25 responden yang memiliki pengetahuan baik adalah ibu hamil usia $>35$ tahun, berpendidikan tamat SMA dan bekerja. Hal ini sudah sesuai dengan teori-teori pengetahuan yang telah dikemukakan sebelumnya bahwa semakin besar usia, semakin tinggi pendidikan, dan memiliki pekerjaan maka akan semakin tinggi pula pengetahuannya. ${ }^{12-3}$

\section{SIMPULAN}

Pada penelitian ini dapat disimpulkan bahwa pendidikan dan pekerjaan berhubungan dengan pengetahuan ibu hamil tentang kontrasepsi sedangkan hasil statistik menunjukkan bahwa usia tidak memiliki hubungan dengan pengetahuan ibu hamil tentang kontrasepsi. Baru setengah dari responden yang memiliki pengetahuan baik tentang kontrasepsi dan yang paling tahu diantaranya memiliki karakteristik yaitu usia ibu diatas 35 tahun, berpendidikan SMA dan bekerja.

\section{SARAN}

Petugas kesehatan perlu mengadakan penyuluhan yang efektif dan memberi pengarahan kepada ibu hamil saat pemeriksaan antenatal terutama kepada ibu hamil dengan usia $<35$ tahun, pendidikannya lebih rendah dari SMA dan tidak bekerja tentang metode kontrasepsi 
yang tersedia dan pentingnya menggunakan kontrasepsi pascapersalinan.

\section{UCAPAN TERIMA KASIH}

Penulis mengucapkan terima kasih yang sebesar-besarnya kepada semua pihak yang telah membantu penulisan artikel ini, terutama dosen pembimbing, keluarga dan sahabat-sahabat. Terima kasih atas dukungan, semangat dan do’anya.

\section{DAFTAR PUSTAKA}

1. Badan Pusat Statistik. Hasil Sensus Penduduk 2010: Data Agregat per Provinsi. Jakarta: Badan Pusat Statistik; 2010. p. 6-7, 10.

2. Ninik P. Hubungan Tingkat Kepatuhan tentang Kontrasepsi Suntik dengan Kepatuhan Jadwal Penyuntikan di Rumah Bersalin An Nissa Surakarta [Skripsi]. [Surakarta]: Universitas Sebelas Maret; 2009.

3. UU No. 52 Tahun 1992 Tentang Perkembangan Kependudukan dan Pembangunan Keluarga [homepage on the internet]. Nodate [cited 2013 Oct 7]. Available from http://datahukum.pnri.go.id/index.p hp?option=com_phocadownload\&v iew

=category\&download=1204:uu52ta hun2009\&id=21:tahun-

2009\&Itemid $=27 \&$ start $=40$.

4. Manuaba I.G.B, Chandranita M, Fajar M. Pengantar Kuliah Obstetri. Jakarta: EGC; 2007.

5. Haryono R. Gangguan dan Penyulit pada Masa Kehamilan. [SumateraUtara]: Universitas Sumatera Utara; 2004.

6. Prawirohardjo S. Ilmu Kebidanan. Jakarta: PT. Bina Pustaka Sarwono Prawihardjo; 2010. p. 58.
7. Badan Kependudukan dan Keluarga Berencana Nasional (BKKBN). Hasil Pelaksanaan dan Sub Pencatatan dan Pelaporan Pelayanan Kontrasepsi Bulan Juli 2013. Jakarta: Direktorat Pelaporan dan Statistik BKKBN; 2013. p. 15, 43.

8. Anwar M, Baziad A, Prabowo R. Ilmu Kandungan (Edisi ke-3): Kontrasepsi. Jakarta: PT. Bina Pustaka Sarwono Prawirohardjo; 2011. p. 436.

9. Kusumastuti FA. Hubungan antara Pengetahuan dan Sikap Seksual Pranikah Remaja [Skripsi]. [Surakarta]: Universitas Sebelas Maret; 2010.

10. Nosaria G, Kirnantoro, Siti F. Effect of Health Education about Hypertension to Level of Knowledge about Hypertension Control in Elderly at Puskesmas Sigaluh 1 Banjarnegara [Skripsi]. [Yogjakarta]: University of Yogjakarta; 2012.

11. Sarampang $\mathbf{Y}$. Hubungan Tingkat Pengetahuan Ibu Melahirkan dengan Pemberian MP-ASI di Bagian Obstetri dan Ginekologi BLU RSU Prof. R. D. Kandou Manado [Skripsi]. [Manado]: Universitas Samratulangi; 2013.

12. Octaviani C. Tingkat Pengetahuan Ibu Nifas tentang Infeksi Luka Perineum di RSU Assalam Gemolong Sragen [Skripsi]. [Surakarta]: Sekolah Tinggi Ilmu Kesehatan Husada; 2012.

13. Kusumawati A. Tingkat Pengetahuan tentang Metode Kontrasepsi Vasektomi pada Pria Usia 35-40 tahun di Desa Babadan Kecamatan Karangdowo Kabupaten Klaten Tahun 2012. [Surakarta]: STIKES Kusuma Husada; 2012. 